\author{
BULETINUL INSTITUTULUI POLITEHNIC DIN IAŞI \\ Publicat de \\ Universitatea Tehnică „Gheorghe Asachi” din Iaşi \\ Volumul 67 (71), Numărul 1, 2021 \\ Secţia \\ CONSTRUCTII DE MAȘINI \\ DOI:10.2478/bipcm-2021-0002 \\ sciendo
}

\title{
THEORETICAL RESEARCH TO IMPROVE THE PERFORMANCE OF A SPARK IGNITION ENGINE BY USING ZONAL COOLING PRINCIPLE
}

BY

\section{TUDOR-MARIAN ULIAN* and ANDREI IONUȚ DONȚU}

“Gheorghe Asachi” Technical University of Iaşi, Faculty of Mechanical Engineering

Received: January 14, 2021

Accepted for publication: March 10, 2021

Abstract. In this paper, it is in focus an analysis and a theoretical study which will develop a mathematical model that will highlight the influences of the thermal regime of a spark plug engine regarding the engine performance improvement.

Keywords: thermal regime; cylinder head temperature; engine cooling; differentiated cooling.

\section{Introduction}

The improvement of the performance of internal combustion engine is based on the thermal optimization and gas dynamics processes.

The experience shows that the optimal temperature of the coolant flowing through the outside of the cylinder should be around $90^{\circ} \mathrm{C}$. Close to this temperature, the cylinder and other components wear is minimal.

Under these conditions, the required temperature distribution along the cylinder's walls is shown in Fig. 1 (Ulian et al., 2018a; 2018b).

*Corresponding author; e-mail: tudor-marian.ulian@academic.tuiasi.ro (C) 2021 Tudor-Marian Ulian et al.

This is an open access article licensed under the Creative Commons Attribution-NonCommercialNoDerivatives 4.0 International License (CC BY-NC-ND 4.0). 


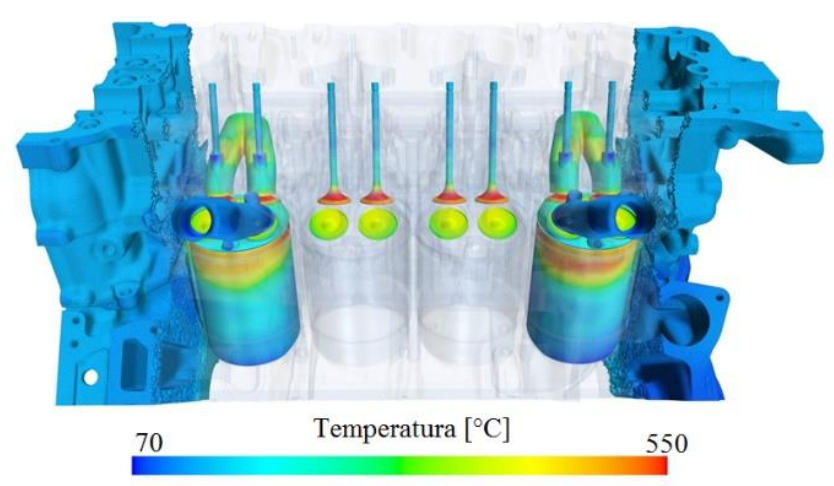

Fig. 1 - Cylinder wall temperature variation (http://mdx2.plm.automation.siemens.com).

Cooling of the cylinder head requires special attention due to the problems caused by non-uniform temperatures distribution. As is known, the cylinder head receives the highest quantity of heat released by combustion.

Tests which were done, (Ainul et al., 2015) show that, in order to increase engine performance, the optimum coolant temperature in the engine cylinder head is approximately $40 \div 60^{\circ} \mathrm{C}$. To obtain this temperature of the cylinder head, were used two independent cooling circuits, one for the cylinder block and one for the cylinder head. A principle like this called differentiated cooling is known and has already been used, without being applied in series production car engines (Ulian et al., 2018a; 2018b).

According to this and starting from the idea of differentiated cooling, authors propose a selective and sequential circulation of liquids involved in the cooling process.

In this context, it is proposed that in the engine warm-up phase, at idle and/or at very low loads, the coolant circulation in the cylinder head be initially zero, and that the circulation speed will increase progressively, in a controlled manner. The coolant temperature of the cylinder head will quickly reach a high value, enough to contribute to the heating of the cylinder block. In the next working sequence, when the temperature of the coolant liquid from the block increase, the temperature of the coolant liquid from the cylinder head will gradually decrease to the previous value, due to the intensification of heat transfer by gradually increasing its circulation speed.

On the other hand, at regimes characterized by low partial loads, the cylinder head does not require too low temperatures, thus respecting the criteria related to cylinder wear, thermal stresses, and environmental pollution.

The continuous regulation of the coolant temperature in accordance with the operating regimes of the engine, was briefly called in this paper, the principle of zonal thermal cooling. 
The schematic of the engine behavior using this principle is suggestively shown in Fig. 2.

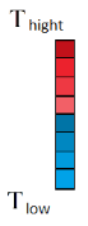

$\mathrm{T}_{\text {hight }}$

$\mathrm{T}_{\text {low }}$

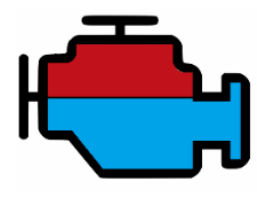

$a$

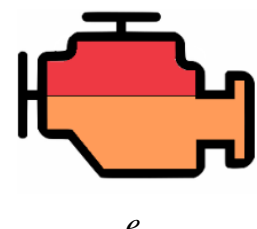

$10 \%$

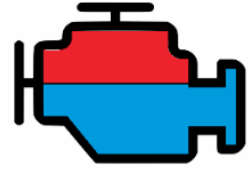

b

Warm-up phase - idle load

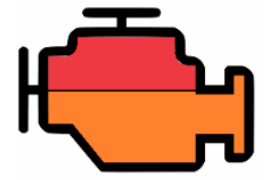

$f$

$15 \%$

Warm-up phase - low partial loads
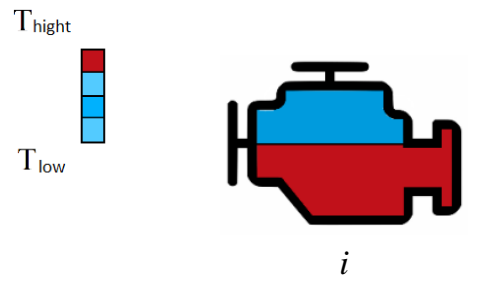

$50 \%$

Warm-up phase - high partial loadsand and full load

Fig. 2 - Warm-up phase of engine cylinder head and cylinder block of for an engine by using zonal cooling principle.

\section{Theoretical Model of Spark Ignition Engine with Zonal Thermal Regime}

Based on the research made in the past (Ulian et al., 2018a; 2018b), where is obtained a function, Eq. (1), that allows the calculation of the volumetric efficiencyin dependence on the change in the coolant temperature from inside the cylinder head in accordance with the principle of zonal cooling of the engine, Fig. 3, we will develop further the mathematically model to highlight the improvement of the engine performance (power and fuel consumption) with zonal thermal regime. 


$$
\begin{aligned}
& \eta_{v}\left(T_{l r}\right)=c_{p} \cdot c_{T m} \cdot c_{\varepsilon} \cdot c_{u p_{2}}^{-1} \cdot c_{e s} \\
& \cdot\left\{c_{u p_{1}}+T_{p c a d m}^{\prime}\right. \\
&-\left[\frac{\alpha_{l}}{\alpha_{m}} \cdot A\left(1+\alpha_{g} \frac{\delta_{1}}{\lambda_{A l}}\right)-\frac{\alpha_{l}+\alpha_{l p r}}{\alpha_{m}}\right] \cdot T_{l r}-\frac{\alpha_{l} \cdot \alpha_{g}}{\alpha_{m}} \\
&\left.\cdot \frac{\delta_{1}}{\lambda_{A l}}\left(T_{g}-B\right)+\frac{\alpha_{l p r}}{\alpha_{m}} \cdot T_{a e r}+\frac{\alpha_{l}}{\alpha_{m}} \cdot B-T_{0}\right\}^{-1}
\end{aligned}
$$

where: $c_{p}=\frac{p_{a}}{p_{0}}-$ pressures constant;

$c_{T m}=T_{0}$ - temperatures constant;

$c_{\varepsilon}=\frac{\varepsilon}{\varepsilon-1}-$ constructive engine constant;

$c_{u p_{2}}^{-1}=1-\varphi_{p u}+\gamma_{r}-$ the second constant that influences the process of filling the cylinder with the fresh charge;

$c_{e s}=1+\gamma_{r}-$ the constant that characterized the exhaust gases from the cylinder;

$c_{u p_{1}}=\gamma_{r} \cdot T_{r}+T_{0}$ - the main constant that influences the process of the cylinder filling with fresh load;

$T_{\text {pcadm }}^{\prime}$-wall temperature of intake channel;

$\alpha_{l}$-convective heat transfer coefficient from the cylinder head walls to the coolant;

$\alpha_{m}$ - weighted average of heat transfer;

$A, B$-coefficients of the polynomial function;

$\alpha_{g}$ - convective heat transfer coefficient from the combustion gases to the inner wall of the cylinder head;

$\delta_{1}$ - wall thickness of the combustion chamber;

$\delta_{2}$ - wall thickness of the intake channel in the cylinder head;

$\lambda_{A l}$ - the conductive heat transfer coefficient of the aluminum alloy of the cylinder head;

$\alpha_{l p r}$ - convective heat transfer coefficient from the cooling liquid to the reduced isothermal equivalent wall, which releases heat to the outside environment;

$T_{l r}$ - coolant temperature from the cylinder head (Ulian et al., 2018a; 2018b). 


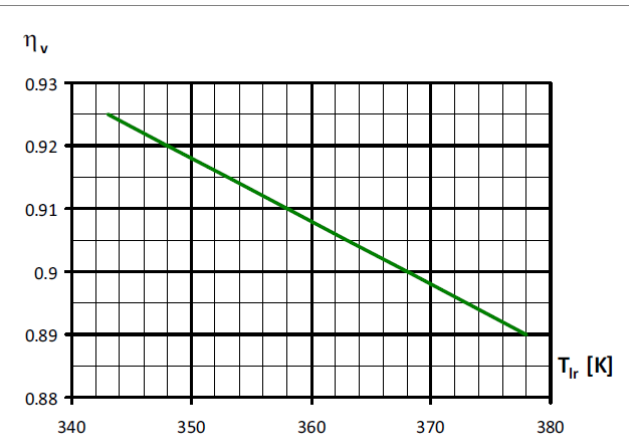

Fig. 3 - Volumetric efficiency in dependence on the coolant temperature.

Using a series of usual relations from the bibliography (Popa and Vintilă, 1977; Rakosi and Manolache, 2007), the specific equations regarding the engine performance with zonal thermal regime are further obtained.

The mathematical model starts from the equation Eq. (2) of the indicated motor power depending on the variation of the volumetric efficiency:

$$
\begin{aligned}
P_{i}=30 \cdot \rho_{0} \cdot n & \cdot i \cdot V_{S} \cdot \frac{Q_{i} \cdot \eta_{i}}{3,6 \cdot 10^{3} \cdot L_{0} \cdot \lambda} \cdot \eta_{v} \\
& =\frac{\pi}{120} \cdot \rho_{0} \cdot D^{2} \cdot S \cdot n \cdot\left(\frac{Q_{i}}{L_{0}}\right) \cdot\left(\frac{\eta_{i}}{\lambda}\right) \cdot \eta_{v}
\end{aligned}
$$

where: $n$-engine speed;

$i=4-$ number of cylinders;

$V_{S}=\frac{\pi \cdot D^{2} \cdot S}{4}-$ engine displacement;

$Q_{i}$ - lower heating value of fuel;

$\eta_{i}$ - indicated mechanical efficiency; of fuel;

$L_{0}$ - the amount of air, theoretically required to burn an amount of $1 \mathrm{~kg}$

$\lambda$ - air-fuel ratio.

Considering the mechanical efficiency of the engine, $\eta_{m}$ the effective power, $P_{e}$ will be:

$$
P_{e}=\frac{\pi}{120} \cdot \rho_{0} \cdot D^{2} \cdot S \cdot n \cdot \eta_{m} \cdot\left(\frac{Q_{i}}{L_{0}}\right) \cdot\left(\frac{\eta_{i}}{\lambda}\right) \cdot \eta_{v}
$$

Considering the variation $\eta_{v}=f\left(T_{l r}\right)$ expressed by the Eq. (1), it appears the possibility to study the dependence $P_{e}=f\left(T_{l r}\right)$.

$$
P_{e}\left(T_{l r}\right) \cong 304 \cdot 10^{-4} \cdot \eta_{m} \cdot n \cdot S \cdot D^{2} \cdot\left(\frac{Q_{i}}{L_{0}}\right) \cdot\left(\frac{\eta_{i}}{\lambda}\right) \cdot \eta_{v}\left(T_{l r}\right)
$$


$\frac{Q_{i}}{L_{0}} \cong 50 \mathrm{~kJ} / \mathrm{kg}$ - correspond to liquid petroleum fuels has a small variation and can be considered constant in this function (Abăintăncei and Bobescu, 1975).

Based on the analysis of data from the literature, this paper proposes a variation, depending on $\lambda$ of the ratio $\left(\eta_{i} / \lambda\right)$, obtained by interpolation (Abăintăncei and Bobescu, 1975; Aramă and Grünwald, 1966). Thus, this variation is defined by the following polynomial function:

$$
\left(\frac{\eta_{i}}{\lambda}\right)=a \lambda^{2}+b \lambda+c
$$

where: $\mathrm{a}=-235.25 ; \mathrm{b}=418.55 ; \mathrm{c}=-83.149$.

Correlating a series of experimental results taken from other works (Abăintăncei and Bobescu, 1975), it can be estimated that at a reduction by $30^{\circ} \mathrm{C}$ of the coolant temperature, $T_{l r}$, shows an increase from 0.8 to 0.98 for the air-fuel ratio $\lambda$, Fig. 4 . Based on these correspondences is proposed a variation of the airfuel ratio $\lambda$, depending on the temperature of the coolant from the cylinder head:

$$
\lambda\left(T_{l r}\right)=L \cdot T_{l r}+\theta
$$

where: $L=-0.006$ și $\theta=1.4003$

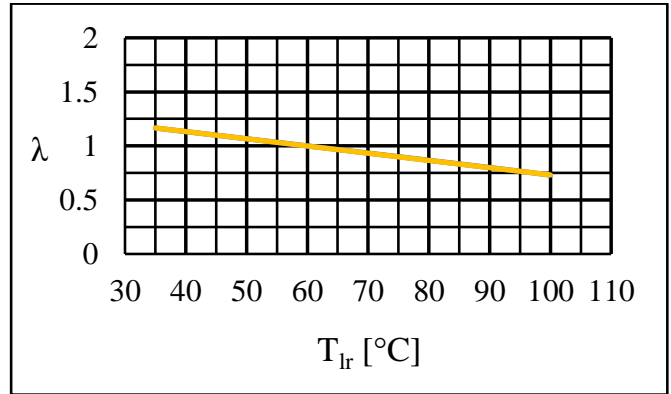

Fig. 4 - Variation of the air-fuel ratio depending on the temperature of the coolant from the cylinder head.

By introducing this variation given by the function (6) in the function (5), we obtain a new one that expresses the dependence of the ratio $\left(\eta_{i} / \lambda\right)$ as a function of the coolant temperature, $T_{l r}$ :

$$
\begin{gathered}
\frac{\eta_{i}}{\lambda}\left(T_{l r}\right)=3.6 \cdot 10^{-5} \cdot T_{l r}^{2}-1.68 \cdot 10^{-2} \cdot a \cdot T_{l r}+1.96 \cdot a \\
-6 \cdot 10^{-3} \cdot b \cdot T_{l r}+1.4003 \cdot b+c
\end{gathered}
$$

The final Eq. (8) for variation of the effective power $P_{e}$ with the coolant temperature, $T_{l r}$ is obtained if we introduce the variation of $\eta_{v}\left(T_{l r}\right)$ according to Eq. (1) and variation ratio $\left(\eta_{i} / \lambda\right)$ form Eq. (7) in Eq. (4), which represent the variation of the effective power $P_{e}$ (Ulian, 2021). 


$$
\begin{aligned}
P_{e}\left(T_{l r}\right) \cong 304 & \cdot 10^{-4} \cdot \eta_{m} \cdot n \cdot S \cdot D^{2} \cdot\left(\frac{Q_{i}}{L_{0}}\right) \\
& \cdot\left(3.6 \cdot 10^{-5} \cdot T_{l r}^{2}-1.68 \cdot 10^{-2} \cdot a \cdot T_{l r}+1.96 \cdot a\right. \\
& \left.-6 \cdot 10^{-3} \cdot b \cdot T_{l r}+1.4003 \cdot b+c\right) \cdot c_{p} \cdot c_{T m} \cdot c_{\varepsilon} \\
& \cdot c_{u p_{2}}^{-1} \cdot c_{e s} \\
& \cdot\left\{c_{u p_{1}}+T_{p c a d m}^{\prime}\right. \\
& -\left[\frac{\alpha_{l}}{\alpha_{m}} \cdot A\left(1+\alpha_{g} \frac{\delta_{1}}{\lambda_{A l}}\right)-\frac{\alpha_{l}+\alpha_{l p r}}{\alpha_{m}}\right] \cdot T_{l r}-\frac{\alpha_{l} \cdot \alpha_{g}}{\alpha_{m}} \\
& \left.\cdot \frac{\delta_{1}}{\lambda_{A l}}\left(T_{g}-B\right)+\frac{\alpha_{l p r}}{\alpha_{m}} \cdot T_{a e r}+\frac{\alpha_{l}}{\alpha_{m}} \cdot B-T_{0}\right\}^{-1}
\end{aligned}
$$

Considering the relationship between power and torque, the function that defines the variation of the effective torque as a function of the coolant temperature $T_{l r}$ is expressed (Ulian, 2021).

$$
\begin{aligned}
M_{e}\left(T_{l r}\right) \cong 29 \cdot & 10^{-2} \cdot \eta_{m} \cdot S \cdot D^{2} \cdot\left(\frac{Q_{i}}{L_{0}}\right) \\
& \cdot\left(3.6 \cdot 10^{-5} \cdot T_{l r}^{2}-1.68 \cdot 10^{-2} \cdot a \cdot T_{l r}+1.96 \cdot a\right. \\
& \left.-6 \cdot 10^{-3} \cdot b \cdot T_{l r}+1.4003 \cdot b+c\right) \cdot c_{p} \cdot c_{T m} \cdot c_{\varepsilon} \\
& \cdot c_{u p_{2}}^{-1} \cdot c_{e s} \\
& \cdot\left\{c_{u p_{1}}+T_{p c a d m}^{\prime}-\left[\frac{\alpha_{l}}{\alpha_{m}} \cdot A\left(1+\alpha_{g} \frac{\delta_{1}}{\lambda_{A l}}\right)-\frac{\alpha_{l}+\alpha_{l p r}}{\alpha_{m}}\right]\right. \\
& \cdot T_{l r}-\frac{\alpha_{l} \cdot \alpha_{g}}{\alpha_{m}} \cdot \frac{\delta_{1}}{\lambda_{A l}}\left(T_{g}-B\right)+\frac{\alpha_{l p r}}{\alpha_{m}} \cdot T_{a e r}+\frac{\alpha_{l}}{\alpha_{m}} \cdot B \\
& \left.-T_{0}\right\}^{-1}
\end{aligned}
$$

The indicated specific fuel consumption is given by the following equation Eq. (10).

$$
c_{i}=3,6 \cdot 10^{3} \cdot \frac{\rho_{0}}{L_{0}} \cdot \frac{1}{\lambda \cdot p_{i}} \cdot \eta_{v}
$$

Considering the mechanical efficiency, $\eta_{m}$ results the equation of the efective fuel consumption:

$$
c_{e}=3,6 \cdot 10^{3} \cdot\left(\frac{\rho_{0}}{L_{0}}\right) \cdot \frac{1}{\eta_{m}} \cdot \frac{1}{\lambda \cdot p_{i}} \cdot \eta_{v}
$$

Considering the variation of the net indicated mean effective pressure depending on the values of the air-fuel ratio, $\lambda$, for the spark ignition engine, the polynomial function describing the variation of this parameter was established by the interpolation method: 
$p_{i}(\lambda)=2.462 \cdot \lambda^{3}-8.279 \cdot \lambda^{2}+8.644 \cdot \lambda+2.226$

If we are introducing this result, as well as the previously established dependencies, $\lambda=f\left(T_{l r}\right)$ and $\eta_{v}=f\left(T_{l r}\right)$, expressed in equations Eq. (6) and Eq. (1), the general function of the variation of the efective specific fuel consumption is obtained:

$$
c_{e}\left(T_{l r}\right)=3.6 \cdot 10^{3} \cdot\left(\frac{\rho_{0}}{L_{0}}\right) \cdot \frac{1}{\eta_{m}} \cdot \frac{1}{\lambda\left(T_{l r}\right)} \cdot \frac{1}{p_{i}(\lambda)} \cdot \eta_{v}\left(T_{l r}\right)
$$
2021):

By successive replacements, the following equation is obtained (Ulian,

$$
\begin{aligned}
c_{e}\left(T_{l r}\right)=3.6 \cdot & 10^{3} \cdot\left(\frac{\rho_{0}}{L_{0}}\right) \cdot \frac{1}{\eta_{m}} \\
& \cdot \frac{1}{60 \cdot T_{l r}^{4}+33 \cdot T_{l r}^{3}+22.6 \cdot T_{l r}^{2}+21.5 \cdot T_{l r}+72.3} \\
& \cdot\left\{c_{p} \cdot c_{T m} \cdot c_{\varepsilon} \cdot c_{u p_{2}}^{-1} \cdot c_{e s}\right. \\
& \cdot\left\{c_{u p_{1}}+T_{p c a d m}^{\prime}-\left[\frac{\alpha_{l}}{\alpha_{m}} \cdot A\left(1+\alpha_{g} \frac{\delta_{1}}{\lambda_{A l}}\right)-\frac{\alpha_{l}+\alpha_{l p r}}{\alpha_{m}}\right]\right. \\
& \cdot T_{l r}-\frac{\alpha_{l} \cdot \alpha_{g}}{\alpha_{m}} \cdot \frac{\delta_{1}}{\lambda_{A l}}\left(T_{g}-B\right)+\frac{\alpha_{l p r}}{\alpha_{m}} \cdot T_{a e r}+\frac{\alpha_{l}}{\alpha_{m}} \cdot B \\
& \left.\left.-T_{0}\right\}^{-1}\right\}
\end{aligned}
$$

\section{Conclusions}

The analysis of the conditions of intake process, especially from the thermal point of view, highlights influences with various implications, which are largely the basis for the development of the theoretical model. This model essentially quantifies the influence of coolant temperature on the cylinder head, concerning the improvement of engine power, engine torque and specific fuel consumption.

\section{REFERENCES}

Abăintăncei D., Bobescu Gh., Motoare pentru automobile, Editura Didactică și Pedagogică București, 1975.

Ainul S., Surjatin W., Azmin S., Mohd R., Fairuz R., Harijono D., Engine Optimization by Using Variable Valve Timing System at Low Engine Revolution, ARPN Journal of Engineering and Applied Sciences, 2015. 
Aramă C., Grünwald B., Motoare cu ardere internă, Editura Didactică şi Pedagogică, Bucuresti, 1966.

Popa B., Vintilă C., Termotehnică şi maşini termice, Editura Tehncă, Bucureşti, 1977.

Rakosi E., Manolache Gh., Procese şi caracteristici ale motoarelor cu ardere internă pentru autovehicule rutiere, Curs, 2007.

Ulian T., Vornicu V., Rakosi E., Manolache Gh., Talif S., Agape I., The Study of the Performance Improvement Possibilities by Using the Principle of Zonal Cooling for the Automotive Engine, The 8th International Conference on Advanced Concepts in Mechanical Engineering, IOP Conf. Series: Materials Science and Engineering, 444, Automotives. Engine and Transmission. Road Safety, 072015, ACME 2018, Iași, doi:10.1088/1757-899X/444/7/072015, 2018a.

Ulian T., Vornicu V., Rakosi E, Talif S., Analysis and Theoretical Modeling of Thermal Influences on the Inlet Process for a Spark-Ignition Engine, The 11th International Conference Interdisciplinarity in Engineering INTER-ENG 2017, 5 - 6 October 2017, Tîrgu-Mureş, Romania, 22, Elsevier, ISSN 2351 - 9789, 683-690, Inter-ENG, Tîrgu-Mureș, 2018b.

Ulian T., Contribuții la ameliorarea performanțelor motorului cu aprindere prin scânteie prin utilizarea unui regim termic zonal, Teză de Doctorat, Universitatea Tehnică “Gheorghe Asachi”, Iași, 2021.

$*^{*}{ }^{*}$ http://mdx2.plm.automation.siemens.com/webinar/addressing-ic-engine-combustionemissions-and-performance-using-latest-3d-cfd-modeling-1.

\section{CERCETĂRI TEORETICE CU PRIVIRE LA ÎMBUNĂTĂȚIREA PERFORMANȚELOR UNUI MOTOR CU APRINDERE PRIN SCÂNTEIE CU REGIM TERMIC ZONAL}

(Rezumat)

În această lucrare, autorii au realizat o analiză și un studiu teoritic cu scopul de a dezvolta un model matematic care să evidențieze influențele regimului termic al motorului cu privire la îmbunătățirea performanțelor acestuia. 